\title{
Agoraphobia: New York City Public Space in the Time of COVID-I 9
}

\author{
Miodrag Mitrašinović \\ Parsons School of Design, The New School \\ mitrasim@newschool.edu
}

\begin{abstract}
This paper explores how the first two waves of the Covid-19 pandemic (February May 2020) in New York City had magnified extreme polarization between two different visions of public space: one clearly represented by the Hudson Yards Plaza in Manhattan, and the other epitomized by the Corona Plaza in Queens. It argues that the phenomenon of agoraphobia, the fear of others, translates into the fear of public space and by extension the fear of democracy driven by deep anxieties surrounding the definition of "the social." This is clearly exemplified by Hudson Yards, which closed its doors to the public in May and approached early bankruptcy. On the other hand, Corona Plaza is still a vibrant public space providing vital social and community services. The Plaza was co-produced by the local communities, city agencies, the non-profit sector and public-private partnership, and it provides a resilient model for the production of public space in NYC. The paper argues that the process of producing an infrastructure of inclusion in Corona, which had preceded the construction of Corona Plaza and was strengthen through it, has enabled the Plaza to strive even during the Covid-19 pandemic.
\end{abstract}

Keywords: New York City, Corona Plaza, infrastructures of inclusion

To cite this article:

Mitrašinović, M. (2020). Agoraphobia: New York City Public Space in the Time of COVID-19. The Journal of Public Space, 5(3), 83-90, DOI 10.3289I/jps.v5i3.I36I

This article has been double blind peer reviewed and accepted for publication in The Journal of Public Space.

(c) (\$) This work is licensed under a Creative Commons Attribution - Non Commercial 4.0 International License https://creativecommons.org/licenses/by-nc/4.0/ 
When the second wave of infections and hospitalizations hit New York City (NYC) in early May, it became evident that nearly sixty percent of new infections came from homes in low-income neighbourhoods, in overcrowded living situations, from northcentral Queens, southeast Brooklyn, and the Bronx. New York State Governor Andrew Cuomo was seemingly surprised to hear the news and said, "When you look at the racial breakdown of who is getting hospitalized, you'll see it is disproportionately minorities. Disproportionately African American and Latino. It always seems that the poorest people pay the highest price. Why is that?" asked Cuomo (NBC 2020). "Let's actually get research and data that can inform us as to why are we having more people in minority communities, more people in certain neighbourhoods, why do they have higher rates of infection," Cuomo said (NYI 2020).

The real question, however, is not 'why that is'-since research on the above is abundant and conclusions are clear-but 'what do we do about it?' And, importantly for this special volume of the Journal of Public Space, what does public space have to do with it?

In early May 2020, four billion people around the world are under lockdown orders due to the COVID- 19 pandemic. Most of the open and public spaces in our cities are deserted. But not all of them. Tracking cell phone location-data in NYC found that the movement of individuals in the top ten percent of the income bracket has come to a standstill, particularly after mid-March when forty percent of them left the city (Quealy 2020); whereas that of the bottom ten percent has increased (Valentino-DeVries et al 2020). Most of the "essential employees"-food-industry workers, police, firefighters, first responders, healthcare workers, delivery, security and maintenance personnel-are in the bottom ten percent and thus must continue to commute despite the risks.

Although overall ridership in NYC's public transportation system has plummeted by ninety percent compared to 2019, subway lines which connect low-income and immigrant neighbourhoods in the outer boroughs with places of employment remain crowded in peak hours. Along Subway Line 7 in Queens, the neighbourhoods of Elmhurst and Corona have been hit the hardest. As recent reports clearly show (Parrott and Moe 2020), many African American and Latino "essential employees" and their families who reside there have been disproportionally impacted by the pandemic. In recent years, the public space imagery symbolic of NYC has been that of the High Line and Hudson Yards. To most New Yorkers, these public spaces—both strongly supported and enabled by Governor Cuomo's administration-represent the Bloomberg-model of urban growth and governance (Brash 20II), and the corresponding radical polarization that has characterized urban development in NYC since 2001 .

Eight miles east of Hudson Yards, at the 103rd Street/Corona Plaza subway stop, along the "International Express" Line 7 (Tonnelat and Kornblum 20I7), one finds a very different model of public space. A quick look at the differences in demographics reveal a stark contrast: eighty four percent of Hudson Yards' residents are US citizens, and nearly seventy percent are US born, and their average annual income is US\$I6IK. Corona's average income is US\$45K, more than sixty percent of its (documented) residents are foreign born, and over twenty percent of them have become naturalized US citizens since 1990 (US Census 2019). Severe overcrowding, public health problems, limited sources of healthy food, outsized rent burdens, as well as a significant number of uninsured residents, make Corona a very fragile urban district. 


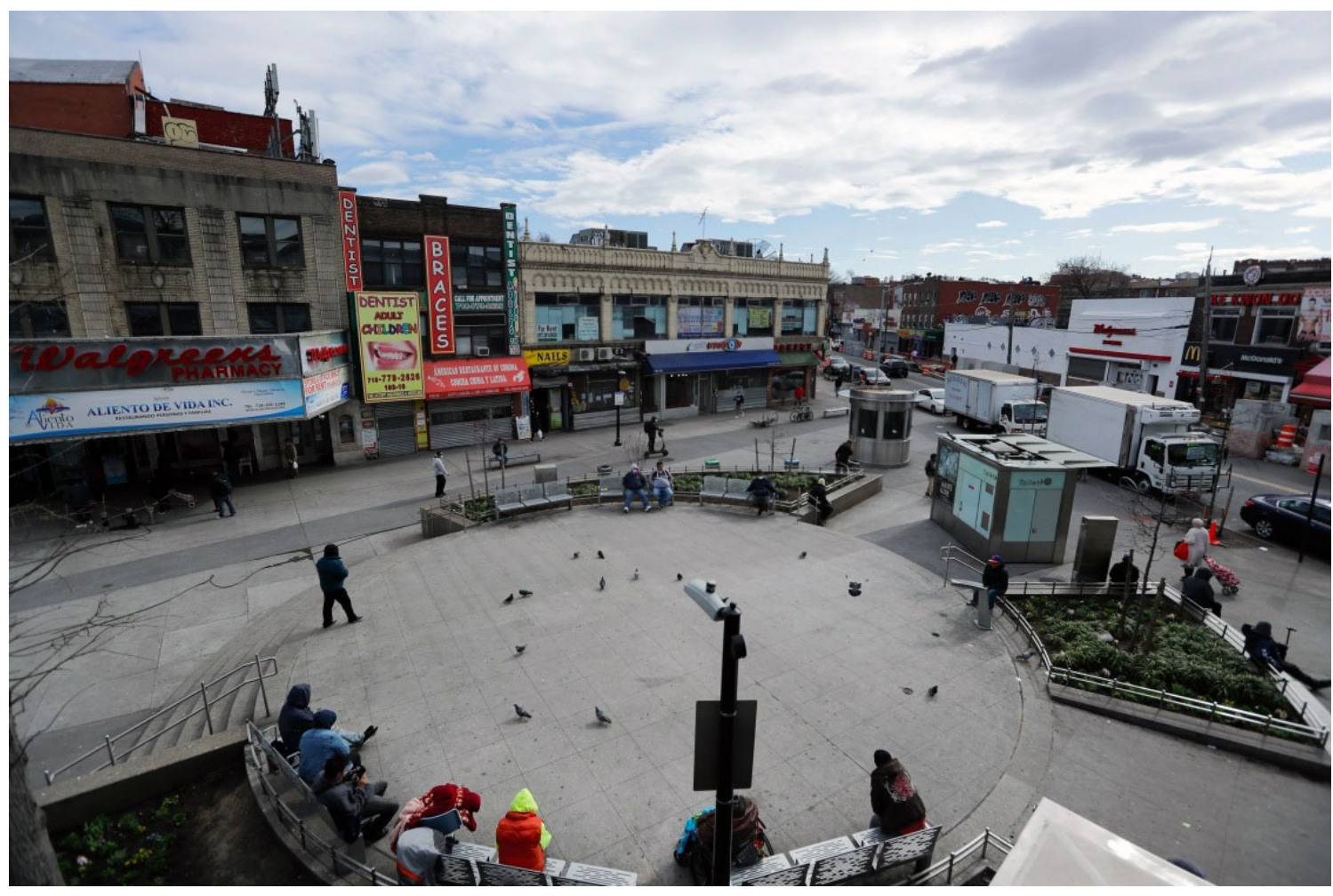

Figure I. Corona Plaza, Queens, April 2020. Photo Credit: Associated Press.

At the same time, the cultural vibrancy and variety of Corona has been well documented: its unique history as well as its cultural, ethnic and racial diversity. Corona Plaza' was developed starting in 2012 on the site of a local thoroughfare and a parking lot adjacent to the 103rd Street Station; a place where developers' trucks picked up daily laborers and food trucks and street vendors lined up along Roosevelt Avenue (Queens Museum of Art 2009). It was developed through the NYC Department of Transportation Plaza Program, through which they have transformed underused spaces adjacent to transportation stops and hubs into vibrant public spaces (NYC DOT 2020).

The program aims to ensure that all New Yorkers-particularly communities of colour and working-class neighbourhoods - live within a 10-minute walking radius from a quality public space. DOT's competitive application process prioritizes neighbourhoods that lack open space, and partners with local organizations and community groups which commit to operate, maintain and manage newly formed pedestrian plazas. In the case of Corona Plaza, the Queens Museum, Queens Economic Development Corporation (EDC), local community organizations, civil society associations, as well as local businesses came together to create a public space where diverse immigrant communities come together.

\footnotetext{
' Data and information used below is derived from public sources, media coverage, author's conversations with various protagonists, as well as from Mogilevich et al 2016.
} 
Agoraphobia: New York City Public Space in the Time of COVID-19

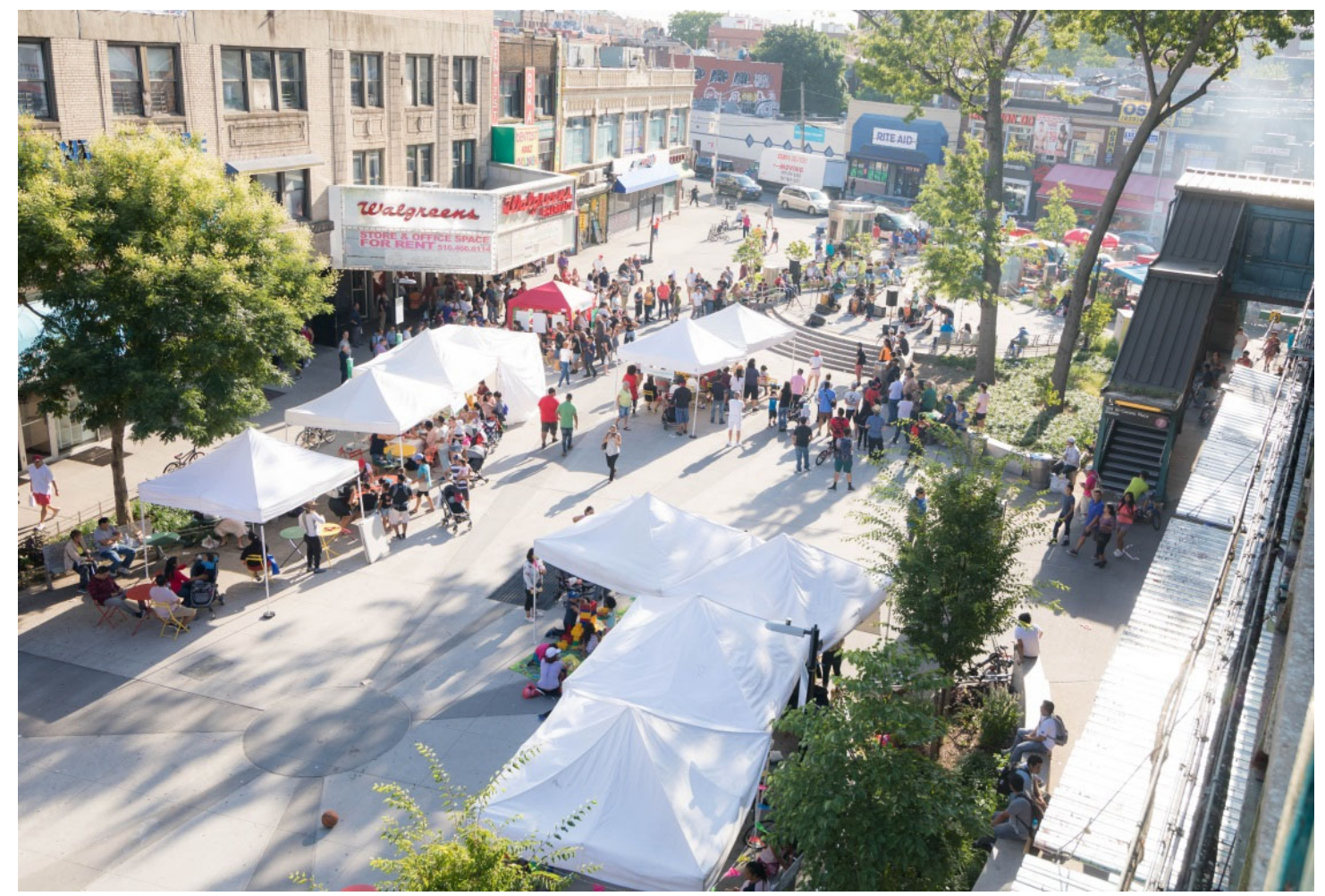

Figure 2. Corona Plaza, Queens, June 2019.

The Corónate festival. Photo Credit: Martin Bolivar and the Queens Museum.

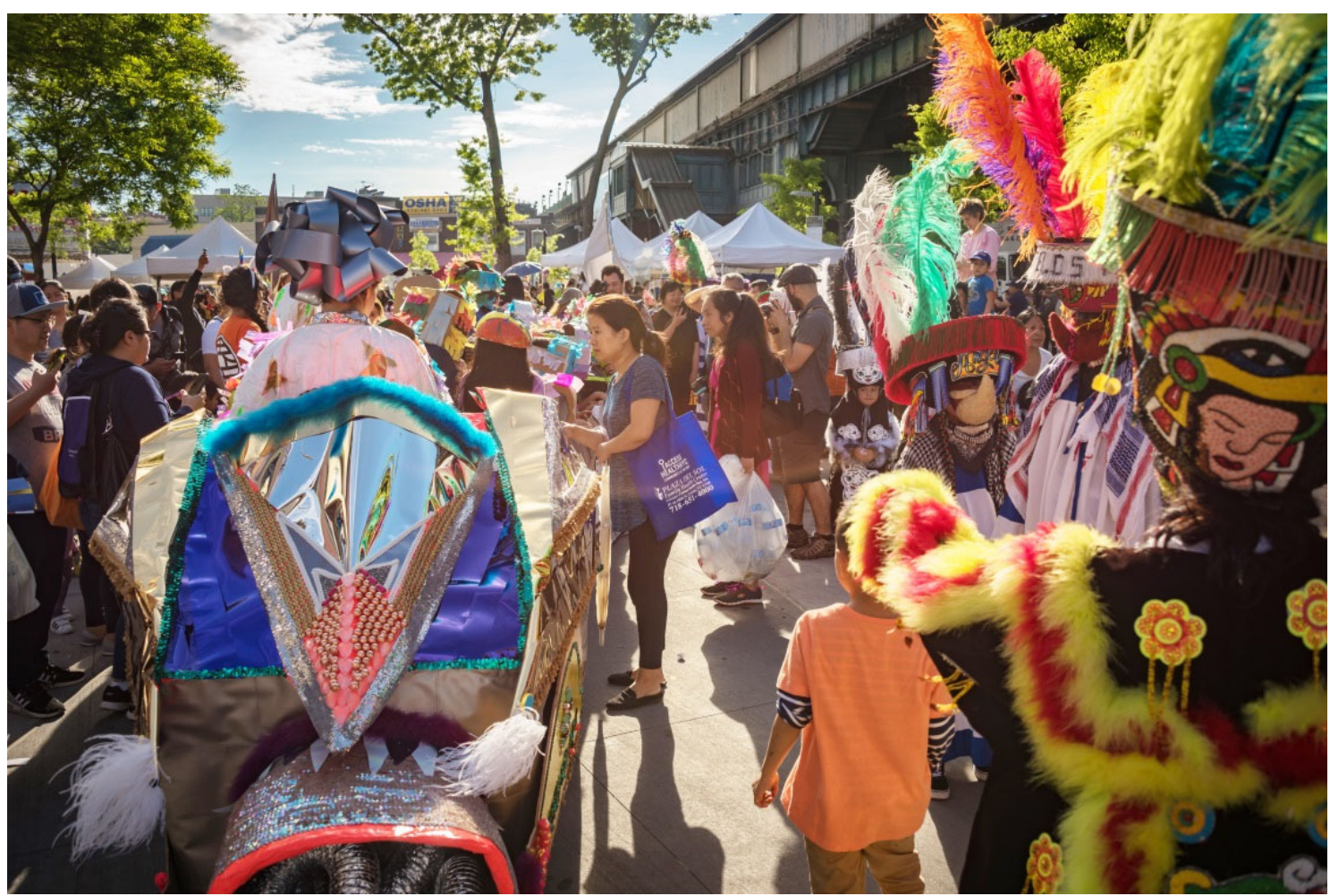

Figure 3. Corona Plaza, Queens, June 2019.

The Corónate festival. Photo Credit: Martin Bolivar and the Queens Museum.

86 | The Journal of Public Space, 5(3), 2020 | ISSN 2206-9658

City Space Architecture / UN-Habitat 
In neighbourhoods like Corona, a central plaza plays the key role as a catalyst for engaging residents in community development, a platform for developing and presenting local cultural producers, a site where community-based organizations could offer and promote social services, and a stimulus to promote health and wellbeing in immigrant communities surrounding the plaza (Mogilevich et al 2016).

As Alexandra García, Queens Museum's Community Organizer and the Corona Plaza Programs Coordinator suggested in 2012, "a dignified public space for immigrants gives more than it takes and offers opportunities of engagement and entertainment that inspire people as creators and participants rather than recipients of services or consumers" (Mogilevich et al 2016: 39). In 2018, after a comprehensive participatory process, Corona Plaza opened in its current configuration with year-long programming of cultural events. During March, April and May 2020 (at the time of this writing), Hudson Yards remains deserted, a ghostly monument to corporate greed and unethical governance, where urban and architectural forms follow finance, surveillance and data harvesting. Corona Plaza, on the other hand, remains active: less busy than usual, and without public events, but still pulsating with each passing of the 7 train. A thriving place only a few months ago, today caution, fear, lack of trust and carefully choreographed movements are evident. Altered food trucks sell personal protective equipment, fruit vendors wear masks and rubber gloves, while neighbours encounter each other with cautious affection.

And yet the paradox of the coronavirus-ravaged New York City is that nearly eighty five percent of all the hospitalized individuals are people who were neither working nor commuting - half being African American and Latino (Higgins-Dunn and Breuninger 2020). They were infected at home by family members who are either essential workers or have to maintain public presence in order to economically sustain family. In Corona, nearly one quarter of housing units are severely overcrowded with multiple generations living together ${ }^{2}$. When in an overcrowded neighbourhood people depend on access to public space in order to provide for their family, and when their families cannot attend public spaces due to the imposed restrictions, there is no feasible way to avoid subsequent infections in their homes.

In her 1996 book Evictions: Art and Spatial Politics, Rosalyn Deutsche titles the last chapter "Agoraphobia" (Deutsche 1996). Agoraphobia is an anxiety disorder induced by the panic fear of open spaces, public transit, parks or streets; basically, a fear of encountering others. As a result, agoraphobic individuals stay at home for extended periods of time and organize their entire lives away from others. In NYC today, even those who never suffered from agoraphobia find themselves avoiding others through panic manoeuvres in public spaces. Nearly sixty percent of low-income, working-class New Yorkers reported that at least one member of their family suffers from anxieties related to COVID-19 (Hester Street Collaborative et al 2020). The "other" is nearly everyone out there, a fact exacerbated by the erosion of trust across social and geographic scales.

\footnotetext{
${ }^{2}$ The NYC Department of Housing Preservation and Development defines a crowded apartment as one in which there's more than one person per room and a severely crowded apartment as one with more than I.5 people per room. Corona, Queens is one the most severely crowded neighbourhoods in NYC, with nearly twenty five percent of all residents living in severely overcrowded conditions. See: Hester Street Collaborative et al 2020.
} 
For Deutsche, agoraphobia translates into the fear of democracy. Namely, the fear of others, and by extension the fear of public space, is driven by deep anxieties surrounding the definition of "the social." Relentless escalation in degrees of inequality has already polarized the urban territory of NYC, and there is no doubt that the ongoing pandemic has intensified this situation. Agoraphobia, no longer just an individual anxiety but also the basis for a political ideology, has forced much of the narrowing down of the spaces of possibility-spaces where we should struggle to define who we want to be as individuals and as a society, what kind of city we want to live in, and how we want to live together. That's why Hudson Yards and Corona Plaza represent such a surreal contrast, and such conflicting political visions of urban life.

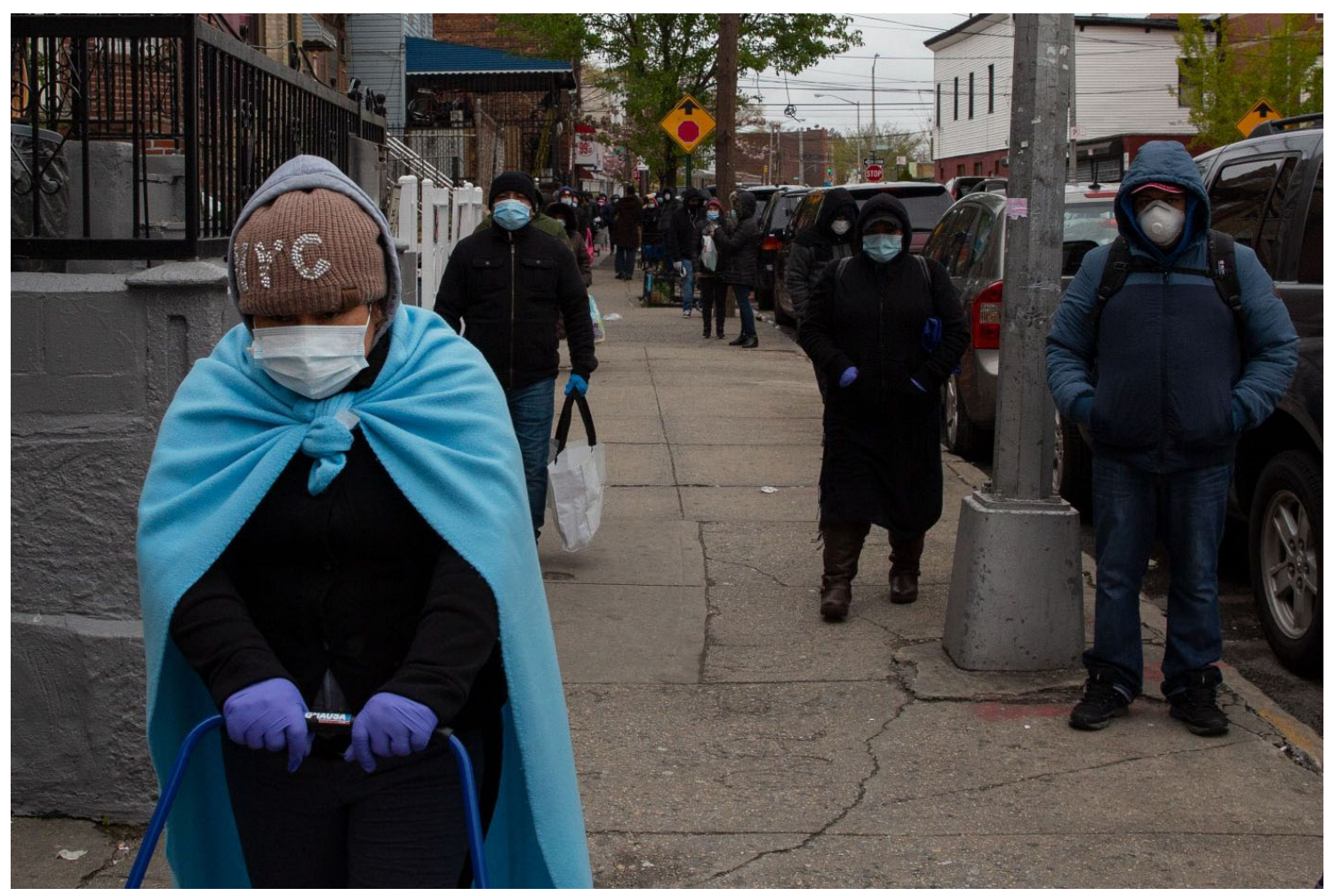

Figure 4: Corona, Queens, April 2020. People waiting for food in front of a community soup kitchen at a local church. Photo Credit: Ben Fractenberg@THE CITY.

How can public space post-COVID-19 be re-imagined as a catalyst for identifying the new meanings of the social, while simultaneously "putting it at risk?" (Lefort, as quoted in Deutsche 1996: 273; Lefort 1986). The only way will be to reject the agoraphobic bourgeois idea that public space is organized on the basis of a stable social consensus and argue that it ought to be configured on the basis of sustaining the search for the genealogies, trajectories and intersections of the struggles and conflicts that make urban life possible. In order to do just that we need democratically constituted public spaces. First, we must rebuild the trust.

What does Corona Plaza offer as a model for the post-COVID-19 conceptions of public space? May 2020 report Excluded in the Epicenter (Hester Street Collaborative et al 2020 ) indicates that during the pandemic, over sixty five percent of low-income, 
working-class New Yorkers have been supported by, and have received valuable information, financial support and critical community-based services from communitybased organizations. In Corona, community organizations not only support residents in time of crisis, but enable differentiated, multiple publics to come together in Corona Plaza, transcend the limitations of isolated communal spaces, and produce a true public space. What they create in the process is what I have elsewhere called "infrastructures of inclusion" (Mitrašinović 2016). Infrastructures are commonly thought of as systems, facilities, services, relations, networks and relationships, as well as the necessary interdependencies, which all cumulatively make a society sustain itself. Infrastructures of inclusion are the types of social-spatial-material infrastructures communities and civic groups build (Simone 2004) to catalyse and sustain processes of transformation-of themselves, their communities and their societies-towards more diverse, democratic, just and inclusive cities, based on the principle of "just distribution justly arrived at" (Harvey 1973: 84). Infrastructure is never only an ensemble of material things; its true character is always relational. In this context, the diverse communities and civic groups in Corona have for a long time been engaged in the praxis of infrastructuring (Manzini 2015) of generating novel configurative possibilities by catalysing processes of solidarity, cooperation, mutual aid, leadership and trust. They have been involved in a collective, collaborative and creative process of configuring new ways of becoming public by cocreating a unique public space.

\section{References}

Brash, J. (20II) Bloomberg's New York: Class and Governance in the Luxury City. University of Georgia Press.

Deutsche, R. (1996) Evictions: Art and Spatial Politics. MIT Press.

Harvey, D. (1973) Social Justice and the City. Johns Hopkins University Press.

Hester Street Collaborative, Make The Road New York, and Center for Popular Democracy (2020) Excluded in the Epicenter: Impacts of the Covid Crisis on Working-Class Immigrant, Black, and Brown New Yorkers. Hester Street. Available at: https://hesterstreet.org/wpcontent/uploads/2020/05/Excluded-in- the-Epicenter_final-compressed.pdf. Last accessed on 14 May 2020.

Higgins-Dunn, N. and Breuninger. K. (2020) "Cuomo Says it's 'Shocking' Most New Coronavirus Hospitalizations are People Who Had Been Staying Home,” CNBC News, 6 May 2020.

Available at: https://www.cnbc.com/2020/05/06/ny-gov-cuomo-says-its-shocking-most-newcoronavirus-hospitalizations-are-people-staying-home.html. Last accessed on 14 May 2020.

Lefort, C. (1986) The Political Forms of Modern Society: Bureaucracy, Democracy, Totalitarianism. MIT Press.

Manzini, E. (2015) Design, when Everybody Designs: An Introduction to Design for Social Innovation. MIT Press.

Mitrašinović, M. (2016) Concurrent Urbanities: Designing Infrastructures of Inclusion. Routledge.

Mogilevich, V. et al. (2016) Corona Plaza Es Para Todos: Making a Dignified Public Space for Immigrants. Queens Museum.

NBC (2020) "Who Are the New COVID- 9 Hospitalizations in New York? The Breakdown Is Worrisome,” NBC 4 news, 6 May 2020. Available at: https://www.nbcnewyork.com/news/coronavirus/who-is-getting-hospitalized-for-covid-19-innew-york- here-is-the-breakdown/2405077l. Last accessed on 14 May 2020. 
NYI (2020) “Minorities Are Being Disproportionately Hurt by Covid-9 in New York City," NYI News, 8 April 2020. Available at: https://spectrumlocalnews.com/nys/centralny/politics/2020/04/08/minorities-are-being-disproportionately-hurt-by-covid-19-in-ny. Last accessed on 14 May 2020.

NYC DOT (2020) New York City Department of Transportation, Pedestrian Plaza Program Guidelines. Available at: https://wwwl.nyc.gov/html/dot/html/pedestrians/nyc-plazaprogram.shtml. Last accessed on I4 May 2020.

Parrott, J.A. and Moe, L. (2020) The New Strain of Inequality: The Economic Impact of Covid- 9 In New York City. Center for New York City Affairs, The New School. Available at: http://www.centernyc.org/reports-briefs/2020/4/I5/ http://www.centernyc.org/reportsbriefs/2020/4/I 5/the-new-strain-of-inequality-the-economic-impact-of-covid-19-in-new-yorkcity. Last accessed on 14 May 2020.

Quealy, K. (2020) "The Richest Neighborhoods Emptied Out Most as Coronavirus Hit New York City,” New York Times, 16 May 2020. Available at: https://www.nytimes.com/interactive/2020/05/I5/upshot/who-left-new-york-coronavirus.html.

Queens Museum of Art (2009) "Reflections from Naila Rosario, QMA's Community Organizer 2006-09," 9 November 2009. Available at: https:/queensmuseum.org/2009/I I/reflectionsfrom-naila-rosario-qmas-community-organizer-2006-09. Last accessed on I4 May 2020.

Simone, A.M. (2004) "People as Infrastructure: Intersecting Fragments in Johannesburg," Public Culture, 16(3): 407-429.

Tonnelat, S. and Kornblum, W. (2017) International Express: New Yorkers on the 7 Train. Columbia University Press.

US Census (2019) United States Census Bureau, New York City data. Available at: https://www.census.gov/quickfacts/fact/table/newyorkcitynewyork/PST0452I8. Last accessed on I4 May 2020.

Valentino-DeVries, J. et al (2020) "Location Data Says It All: Staying at Home During Coronavirus Is a Luxury,” New York Times, 14 May 2020. Available at: https:/www.nytimes.com/interactive/2020/04/03/us/coronavirus-stay-home-rich-poor.html. Last accessed on 14 May 2020. 